\title{
Quality Improvement of Oil Palm Waste-Based Feed Product Through Indigenous Microbial Fermentation to Reach Sustainable Agriculture
}

\author{
Yunilas", Lili Warly", Yetti Marlida\#, Irsan Riyanto * \\ \# Department of Agriculture, University of North Sumatera, Medan, Indonesia \\ E-mail: yunilas11@yahoo.co.id, liliwarlyuapdg@yahoo.co.id,yettimarlida@yahoo.com, \\ * Department of Animal Husbandry, University of Andalas, Padang, Indonesia \\ E-mail:rio_sanda@yahoo.co.id
}

\begin{abstract}
This study aims to improve the quality of oil palm waste-based feed product through indigenous microbial fermentation. The methods used Factorial Completely Randomized Design (CRD) with a pattern of $3 \times 4$ with 3 replications. Treatment of factor I was the substrat combination of oil palm waste and factor II the inoculum combination of microbial. Parameters which is observed such as: dry matter, crude protein, and crude fiber. The result showed that the uses of inoculums of indigenous microbial (Bacillus YL.B1, Trichordema YL.F8, Yeast YL.YS3) fermentation on oil palm created a significant improvement $(P<0.01)$ by increasing crude protein content and decreasing crude fiber content. It caused the crude protein content up to $57.65 \%$ and crude fiber content down to $15,60 \%$. This study proved that the uses of indigenous microbial fermentation improved the quality of oil palm-based waste feed product to reach sustainable agriculture.
\end{abstract}

Keywords - Indigenous microbes, feed quality, oil palm waste.

\section{INTRODUCTION}

Oil palm is the excellent of plant plantations which highly in demand by businessmen of Indonesian export commodities. Plantation area of continues to increase rapidly every year along with the increasing demand for palm oil industry products. Based on (1), oil Palm plantation area reached 7.8 million ha. In each ha of oil palm plantations produce about 6.8 tons of oil palm frond, oil palm sluge, palm kernel cake, freshly fiber and empty bunches. Every tonne of fresh fruit bunches, oil palm sludge produces 294 $\mathrm{kg}, 35 \mathrm{~kg}$ of palm kernel cake and $180 \mathrm{~kg}$ of oil cake fruit fiber.

From by-product of plantation and industry of oil palm obtained a large amount of waste such as oil palm frond, oil palm sluge, palm kernel cake, palm fiber and palm empty fruit bunches. By-products of industrial oil palm plantations is potentially quite large as a source of feed for ruminants is available in large quantities. However, from potential, and enabling this waste, there are some things that become a limiting factor utilization as animal feed, among others, the low protein content and high fiber content. The results of the analysis of oil palm waste was oil palm frond containing $5.08 \%$ crude protein, $36.11 \%$ crude fiber, crude fat $4.71 \%$ to $92.21 \%$ dry matter. Oil palm sludge containing $4.89 \%$ crude protein, $18.17 \%$ crude fiber, crude fat $18.43 \%$ to $84.53 \%$ dry matter, while palm kernel cake containing $19.28 \%$ crude protein, $16.84 \%$ crude fiber, crude fat $11.66 \%$ with $90.63 \%$ dry matter. The high fiber content can reduce the level of feed digestibility.

The low digestibility of is caused by the bonding between lignin and carbohydrates (2). Cause low digestibility of feed derived from these wastes can not be utilized optimally. In order to improved digestibility and nutritional value of the feed-based waste oil palm plantations should receive treatment through touch technology. One of the feedstuff processing technology is biofermentasi feed using indigenous microbes.

Indigenous microbes are microbes that are exploited than the substrate itself that has the ability to optimally degrade the substrate. Through the exploration of indigenous microbes will produce multi-enzyme that plays an important role in feed processing. Based on the results of the isolation of indigenous microbes from waste palm plantations on a modified selective media obtained some cellulolytic microbes that have the ability degaradasi fibers such as bacteria Bacillus YL.B1, fungi Trichordema YL.F8 and Yeast YL.YS3.

The result of this isolation is explicitly adds a wealth of biodiversity of bacterial, fungal and yeast Indigenous Indonesia. Activity in the process biofermentasi need to be 
developed and improved. Indigenous microbes (Bacillus YL.B1, Trichordema YL.F8 and Yeast YL.YS3) as microbes to degrade the fiber will be used primarily in biofermentasi industrial waste and oil palm plantations.

The indigenous microbes able to change the inorganic sources of $\mathrm{N}$ into organic $\mathrm{N}$ (true protein) so that there increase crude protein.

Fermentation can increase digestibility (3), adds flavor and aroma as well as increasing the content of vitamins and minerals. Moreover, fermentation is an oxidation-reduction reaction that produces energy in biological systems obtained in an anaerobic atmosphere. Yeast is used as fermentor which contains various microbes (4). Fermentation using Bacillus YL.B1 from oil plantation waste produce the enzyme cellulase, xylanase and manase that able to break down food substances that are difficult to digest (5). It is in line with the statement (6), fermentation is expected to break down complex substances in food to improve digestion and nutritional value.

Based on the above, it is necessary to research about fermentation of oil palm waste using indigenous microbes to lower crude fiber content and increase the nutritional value.

\section{MAterial AND Methods}

Research was conducted in Animal Science Department, Agriculture Faculty, Nort Sumatra University. Materials used in this research were the Oil Palm waste (oil palm frond, palm kernel cake, oil palm sludge) (fig.1). The Indigenous microbial (Bacillus YL.B1, Trichordema YL.F8 dan Yeast YL.YS3) (fig.2), Nutrient agar (NA), PDA, PDYA and distilled water.
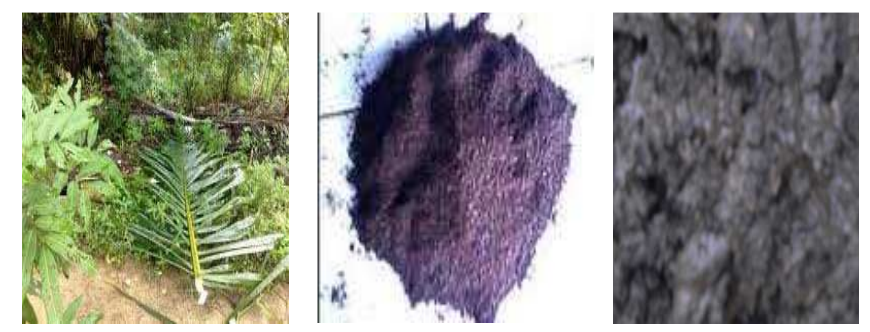

Fig. 1 The Oil Palm waste (oil palm frond, palm kernel cake, oil palm sludge)

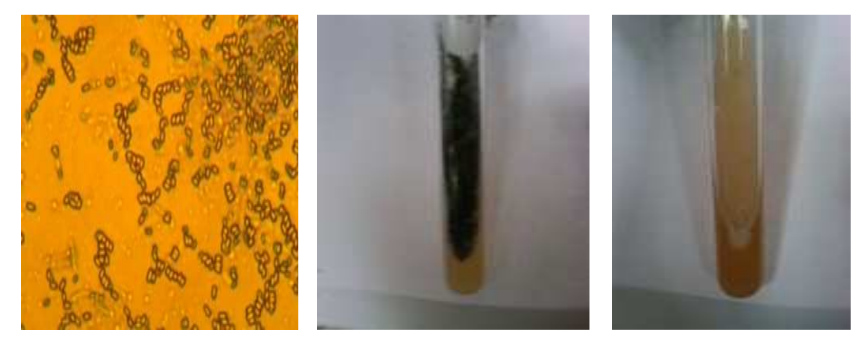

Fig. 2 Indigenous microbial from oil palm waste (Bacillus YL.B1, Trichordema YL.F8 dan Yeast YL.YS3)

The methods used Factorial Completely Randomized Design (CRD) with a pattern of $3 \times 4$ with 3 replications. Treatment of factor I was the substrat of oil palm waste and factor II the inoculum various of microbial. (7). The factor I of the treatment was P1 (80\% oil palm frond, $10 \%$ palm kernel cake and $10 \%$ oil palm sludge), P2 (60\% oil palm frond, $20 \%$ palm kernel cake and $20 \%$ oil palm sludge), P3 (40\% oil palm frond, $30 \%$ palm kernel cake and $30 \%$ oil palm sludge), while factor II was the indigenous microbial was M1 (bakteri and fungi), M2 (bakteri and yeast), M3(fungi and yeast), M4 (bakteri, fungi and yeast). Parameters which is observed such as: dry matter, crude protein and crude fiber content.

\section{RESULTS AND DISCUSSION}

\section{A. Effect of Fermentation of Oil Palm waste with Indigenous Microbial on Dry Matter}

Average of dry matter content after fermented oil palm waste ranged from 86,92 - 92,55\% (Table 1). Results of analysis of variance shows that the interaction between the substrat and inoculum, the inoculum various and substrat showed significantly different effects $(\mathrm{P}<0.01)$ on dry matter. Duncan's Multiple Range Test showed that the use of inoculum of M4 was significantly different with M1, M2 and M3 ( $\mathrm{P}<0.01)$ on the dry matter, while M1 was not significantly different to the M3 and M2 significant difference with M1 and M3. It appears that the variation of the inoculum used in the fermentation greatly affect the levels of dry matter produced. Lowest dry matter obtained in the use of inoculums M1 (bacteria and fungi) and this result was not significantly different with inoculums M3 (Fungi and yeast).The entire document should be in Times New Roman or Times font. Type 3 fonts must not be used. Other font types may be used if needed for special purposes. Recommended font sizes are shown in Table 1.

TABLE I

Average Of Dry Matter Content Of Oil Palm Waste

\begin{tabular}{ccccc}
\hline \multirow{2}{*}{ Inoculum } & \multicolumn{2}{c}{ Substrat (Oil Palm Waste) } & \multirow{2}{*}{ Average } \\
\cline { 2 - 4 } & P1 & P2 & P3 & \\
\hline M1 & 88,74 & 87,26 & 89,08 & $88,36^{\mathrm{c}}$ \\
M2 & 89,35 & 90,49 & 87,85 & $89,23^{\mathrm{b}}$ \\
M3 & 89,16 & 89,93 & 86,92 & $88,67^{\mathrm{c}}$ \\
M4 & 88,67 & 90,57 & 92,55 & $90,59^{\mathrm{a}}$ \\
\hline Average & $88,98^{\mathrm{b}}$ & $89,56^{\mathrm{a}}$ & $89,10^{\mathrm{b}}$ & \\
\hline
\end{tabular}

Note: Different superscripts among treatments show significantly different effects $(P<0.01)$.

During the fermentation process of microbial will synergy, so that more and more opportunities to grow and the microbes produce enzymes that will be used to degrade components of the fibers contained in the substrate. The end product of the degradation of crude fiber on the substrate in the form of glucose to be used as a source of energy for microbial life that needs dry matter substrate decreases. As such allegedly degradation activity in the treatment of M1 and M3 is higher than the other treatments so that dry matter value is lower than the other treatments. This is consistent with the statement (8), microorganisms use carbohydrates as an energy source after broken down into glucose, the glucose solution was continued until finally formed energy and water as well as the carbon dioxide molecules.

Similarly, the effect of treatment on the various substrate fermentation on the content of dry matter. Duncan's Multiple Range Test showed no significantly different P1 P3 P2 but significantly different. This indicates microbial activity in 
the P1 and P3 mendegaradasi substrate is higher than P2. Allegedly komposisis fiber components on the substrate causes adaptation and microbial activity to degrade the substrate P1 and P3 higher earned so that dry matter is lower.
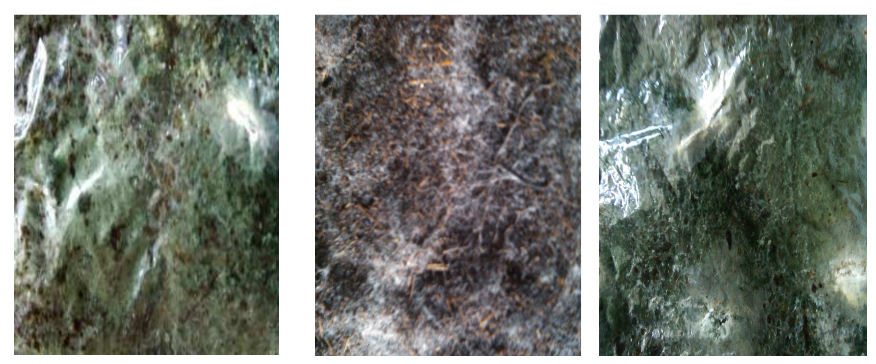

Fig. 3 Result of fermentation of oil palm waste with Indigenous microbial

\section{B. Effect of Fermentation of Oil Palm Waste with}

Indigenous Microbial on The Crude Protein Content

The average crude protein content of oil palm waste after fermented with inoculum (indigenous microbial) ranged from 8,64 - 13,69\%, which after fermented the crude protein content increased about 9,03 - 57,65\%. The crude protein content of oil palm waste can be seen in Table 2.

TABLE II

Average Of Crude Protein Content Of Oil Palm Waste

\begin{tabular}{|c|c|c|c|c|}
\hline \multirow{2}{*}{ Inoculum } & \multicolumn{3}{|c|}{ Substrat (Oil Palm Waste) } & \multirow{2}{*}{ Average } \\
\hline & P1 & $\mathbf{P 2}$ & P3 & \\
\hline M1 & 8,64 & 11,26 & 13,69 & $11,20^{\mathrm{tn}}$ \\
\hline M2 & 8,91 & 12,40 & 13,25 & $11,52^{\text {tn }}$ \\
\hline M3 & 9,93 & 12,23 & 13,63 & $11,93^{\mathrm{tn}}$ \\
\hline M4 & 9,83 & 12,54 & 12,80 & $11,72^{\text {tn }}$ \\
\hline Average & $9,33^{\mathrm{c}}$ & $12,11^{\mathrm{b}}$ & $13,34^{\mathrm{a}}$ & \\
\hline
\end{tabular}

Note:Different superscripts among treatments show significantly different effects $(\mathrm{P}<0.01)$

Results of analysis of variance shows that the interaction between the substrat and inoculum various on crude protein content showed different effects are not significant $(\mathrm{P}>$ $0.05)$, while the fermentation inoculum also give different effects are not significant $(\mathrm{P}>0.05)$, but the various of a substrat was affects hight significant effect on crude protein content $(\mathrm{P}<0.01)$.

Duncan's Multiple Range Test showed that the fermentation by microbes indigenous to the substrate P3 (40\% of oil palm Frond, $30 \%$ palm kernel cake and $30 \%$ of oil palm sludge) increase the crude protein content is higher than P1 $(80 \%$ of oil palm Frond, $10 \%$ palm kernel cake and palm oil sludge $10 \%)$ and P2 (60\% of oil palm Frond, $20 \%$ palm kernel cake and palm oil sludge $20 \%$ ). The increase in crude protein content caused microbes can utilize tissue substat to form or grow. High microbial growth that will result in a high crude protein as well because microbial bodies composed mostly of proteins. Besides, all the polysaccharide components contained in P3 is more easily degraded than the indigenous microbial P2 and P1, so that the fermentation is not only going to increase the protein content will also increase the digestibility feed later.

Microbial growth would be maximized if the conditions are suitable primarily desired concentration of substrate and the concentration of the food source for microbial growth.
Further said microorganisms (microbes) require carbon with the main objective for the formation of cells and source of energy, and nitrogen serves as forming protoplasm and cell walls (9). Comparison of $\mathrm{C}: \mathrm{N}$ for microorganisms needs to have enough range widely depending on the type of substrate and microorganisms such as examples of wood degradation by white root fungus has a range of $\mathrm{C}$ : $\mathrm{N}$ between 160: 400 which is influenced primarily lignin content of fiber components (10).

\section{Effect of Fermentation of Oil Palm Waste with}

Indigenous Microbial to The Crude Fiber Content. The average crude fiber content of oil palm waste after fermented with inoculum (Indigenous microbial) ranged from 19,92 $28,87 \%$, which after fermented the crude fiber content decreased up to $15,60 \%$. The crude fiber content of oil palm waste can be seen in Table 3 .

Results of analysis of variance shows that the interaction between the substrat and inoculum various showed different effects not significant $(\mathrm{P}>0.05)$ on crude fiber content, while the inoculum various and substrat affects hight significant effect on crude fiber content $(\mathrm{P}<0.01)$.

TABLE III

Average Of Crude Fiber Content Of OIL PAlm Waste

\begin{tabular}{ccccc}
\hline \multirow{2}{*}{ Inoculum } & \multicolumn{3}{c}{ Substrat $($ Oil Palm Waste) } & \multirow{2}{*}{ Averagee } \\
\cline { 2 - 4 } & $\mathbf{P 1}$ & $\mathbf{P 2}$ & $\mathbf{P 3}$ & \\
\hline M1 & 28,87 & 23,75 & 22,20 & $24,94^{\mathrm{a}}$ \\
M2 & 28,34 & 23,79 & 21,34 & $24,49^{\mathrm{a}}$ \\
M3 & 27,07 & 22,77 & 19,92 & $23,25^{\mathrm{b}}$ \\
M4 & 28,41 & 23,68 & 20,69 & $24,26^{\mathrm{a}}$ \\
\hline Average & $28,17^{\mathrm{a}}$ & $23,49^{\mathrm{b}}$ & $21,04^{\mathrm{c}}$ & \\
\hline
\end{tabular}

Note:Different superscripts among treatments show significantly different effects $(\mathrm{P}<0.01)$.

Duncan's Multiple Range Test showed that fermentation using inoculum M3 can reduce the content of SK was higher than other treatments. It can caused due to a better synergy of microbial inoculums M3 compared to other treatments. With a good synergy between the microbes causing the greater the chance of microbial fermentation processes and work in the more substrates are degraded, so that decrease in the higher fiber content.

Based DMRT showed that the decrease in the fiber was higher in P3 than the other treatments. This can be caused by differences in the composition of the polysaccharide substrate perlakuaan highly affect the working of microbes in the fermentation process. Allegedly P3 substrate contains more cellulose than crystalline amorphous form. (11) stated that the crystalline portion of the cellulose is difficult and not easily react with a endo cellulase enzymes but the amorphous easily hydrolyzed by the enzyme endo or exoselulase or acid solution.

\section{CONCLUSIONS}

Based on the research results, it was concluded that palm oil waste fermentation with indigenous microbes can increase the crude protein content and lower crude fiber content. With waste fermented palm plantations using indigenous microbes can increase digestibility feedstuffs based waste oil palm plantations. 


\section{ACKNOWLEDGMENT}

I would like to thank for my Advisors for correct this full paper for to publish at International Journal on Advance Sciences, Engineering and Information Technology (IJASEIT).

\section{REFERENCES}

[1] Direktorat Jenderal Perkebunan. Luas Areal Dan Produksi Perkebunan SeluruhIndonesia Menurut Pengusahaan "Komoditi Kelapa Sawit". Jakarta.2010.

[2] Lynd, L.R., P.J. Weimer, W.H. van Zyl, and I.S. Pretorius. Microbial Cellulose Utilization: Fundamentals and Biotechnology. Microbiology and Molecular Biology Reviews 66 (3): 506-577. 2002.

[3] Winarno, F.G.S., D. Fardiaz and D. Fardiaz. Introduction to Food Technology. Gramedia, Jakarta. 1980.

[4] Sa'id, E.G. Introduction to BioIndustry. AgroIndustri Press Department of TIN Faperta, IPB, Bogor. 1997.
[5] Yunilas. Potency of Indigenous Bacteria from oil Palm Waste in Degrades Lignocellulose as a Sources of Inoculum Fermented to High Fiber Feed. Pakistan Journal of Nutrition. 12 (9): 851-853. 2013.

[6] Supriyati, T. Pasaribu, H. Hamid dan A. Sinurat. Palm Kernel Cake is fermented Solid Substrates by Using the Aspergillus niger, J. Ilmu Ternak Vet. 4(4) : 257-263. 1998.

[7] Steel, R. G. D. \& J. H. Torie. Principles and Procedures of Statistics. An Approach of Biometrik. PT. Gramedia Pustaka Utama, Jakarta. 1995.

[8] Fardiaz, S. Mikrobiologi Pangan. Direktorat Jenderal Pendidikan Tinggi Departemen Pandidikan dan Kebudayaan, Kerjasama Pusat Antar Universitas Pangan dan Gizi, IPB, Bogor. 1989.

[9] Standbury,P.F and A.Whitaker. Principles of Fermentation Technology. New York: Pergamon Press. 1984.

[10] Eriksson, K.E.., A. Grunewald and L.Vallander. Sudies of the Growth Conditions in Wood of Three White Rot Fungi and Their Cellulose-Less Mutants. Biotechnol. Being.22, 363-376. 1980.

[11] Sinitsyn, A.P., A.V. Gusakov and E. Yu Vlasenco. Effect of structural and physic-chemical features of cellulosic substrates on the efficiency of enzymatic hydrolysis. Applied biochemistry and biotechnology 30, 43-59. 1990. 